\title{
IMPLEMENTASI MODEL PEMBELAJARAN DISCOVERY UNTUK MENGETAHUI KETERAMPILAN DASAR BEKERJA ILMIAH MAHASISWA IAIN PALU
}

\author{
Mirnawati \\ Program Studi Tadris IPA, FTIK, Institut Agama Islam Negeri Palu \\ miralamanimpa@gmail.com
}

\begin{abstract}
ABSTRAK
Penelitian ini bertujuan untuk mengetahui perbedaan pengetahuan keterampilan dasar bekerja ilmiah pada mahasiswa di kelas. Penelitian ini menggunakan metode Quasi Eksperiment dengan desain penelitian The Non Equivalen, Pretest-Postest Design. Sampel penelitian terdiri dari 30 orang mahasiswa PGMI IAIN Palu. Teknik pengambilan sampel yang digunakan adalah Simple Random Sampling. Teknik pengumpulan data yaitu menggunakan lembar observasi. Teknik analisis data menggunakan uji Normalitas, uji Homogenitas, dan uji t dengan menggunakan program IBM SPSS Statistics 22 dan Microsoft Excel. Hasil penelitian menunjukkan nilai signifikansi Sig (2-Tailed) adalah $0,00<0,05$ yang berarti $\mathrm{H}_{0}$ ditolak dan $\mathrm{H}_{1}$ diterima. Diperoleh dari data perbedaan pengetahuan keterampilan dasar bekerja ilmiah untuk mahasiswa yang menggunakan model pembelajaran Konvensional dan untuk mahasiswa yang menggunakan model pembelajaran Discovery Learning. Dapat disimpulkan bahwa terdapat perbedaan pengetahuan yang signifikan antara mahasiswa yang menggunakan model pembelajaran konvensional dengan siswa yang menggunakan model pembelajaran Discovery Learning pada matakuliah Konsep Dasar IPA.
\end{abstract}

Kata Kunci: Bekerja Ilmiah, Discovery Learning, Konsep Dasar IPA

\begin{abstract}
This study aims to determine the differences in knowledge of basic scientific work skills in students in the classroom. This research uses the Quasi Experiment method with The Non Equivalent, Pretest-Postest Design research design. The research sample consisted of 30 PGMI IAIN Palu students. The sampling technique used is Simple Random Sampling. Data collection techniques are using observation sheets. Data analysis techniques using the Normality test, Homogeneity test, and $t$ test using the IBM SPSS Statistics 22 and Microsoft Excel programs. The results showed the significance value of Sig (2-Tailed) was $0.00<0.05$ which means that $\mathrm{H} 0$ was rejected and $\mathrm{H} 1$ was accepted. Obtained from data on differences in knowledge of basic scientific work skills for students who use the conventional learning model and for students who use the Discovery Learning learning model. It can be concluded that there is a significant difference in knowledge between students who use conventional learning models and students who use Discovery Learning learning models in the Science Concept Basic courses.
\end{abstract}

Keywords: Scientific Work, Discovery Learning, Basic Concepts of Natural Sciences

\section{PENDAHULUAN}

Ilmu Pengetahuan Alam (IPA) tidak akan pernah lepas dari kegiatan sehari-hari semua manusia. IPA adalah kumpulan teori yang sistematis, penerapannya secara umum terbatas pada gejala-gejala alam, lahir dan berkembang melalui metode ilmiah seperti observasi dan eksperimen serta menuntut sikap 
ilmiah seperti rasa ingin tahu, terbuka, jujur, dan sebagainya.

Dari sekian banyak tujuan pembelajaran IPA, yang menjadi fokus utama dalam permasalahan yang akan diangkat dalam penelitian ini yaitu "melakukan inkuiri ilmiah untuk menumbuhkan kemampuan berpikir, bersikap, dan bertindak ilmiah serta berkomunikasi". Secara ideal, banyak tuntutan yang seharusnya dapat dipenuhi oleh mahasiswa. Sayangnya, masih banyak kekurangan yang terdapat diberbagai aspek pembelajaran. Seperti, kurangnya tenaga pengajar yang profesional serta sarana dan prasarana yang belum mendukung. Padahal dengan semua kekurangan yang ada tersebut, mahasiswa tetap dituntut untuk memahami dengan baik atau bahkan berhasil pada setiap mata kuliah yang ada di jurusan PGMI. Berdasarkan kerangka pemikiran yang telah diungkap di atas, peneliti tertarik untuk melakukan suatu penelitian tentang Implementasi Model Pembelajaran Discovery untuk Mengembangkan Keterampilan Dasar Bekerja Ilmiah Mahasiswa pada Materi Indera Penglihatan dan Alat Optik. Dengan demikian "Implementasi Model Pembelajaran Discovery untuk Mengembangkan Keterampilan Dasar Bekerja Ilmiah Mahasiswa Jurusan PGMI Fakultas Tarbiyah dan Ilmu Keguruan IAIN Palu" sangatlah penting untuk dilakukan. Berdasarkan latar belakang yang telah dikemukakan, maka dapat dirumuskan masalah sebagai berikut: "Apakah terdapat perbedaan perkembangan keterampilan dasar bekerja ilmiah antar mahasiswa di kelas yang mendapat model pembelajaran discovery dibandingkan dengan kelas yang mendapat model pembelajaran konvensional?"

\section{METODE PENELITIAN}

Penelitian ini merupakan penelitian kuasi eksperimen yang mengupayakan pengontrolan terhadap satu variabel dominan terhadap variabel yang lain karena bertujuan untuk mendiskripsikan letak dan penyebab perbedaan perkembangan keterampilan dasar bekerja ilmiah mahasiswa PGMI dalam memahami dan menyelesaikan soal-soal mata kuliah Konsep Dasar IPA. Ditinjau dari pendekatan analisisnya, penelitian ini terbagi atas dua yaitu: (1) Pendekatan kuantitatif digunakan untuk menghitung prosentase perkembangan keterampilan dasar bekerja ilmiah, (2) pendekatan kualitatif digunakan untuk menentukan analisis observasi, terhadap subjek.

Keterampilan dasar bekerja ilmiah adalah kecakapan yang dimiliki siswa pada saat pembelajaran sedang berlangsung yang diukur dengan penialain kinerja (asesmen kinerja menggunakan lembar observasi siswa) melalui perluasan metode ilmiah yang terdiri atas berbagai aktifitas seperti (1) mengamati; (2) mengajukan pertanyaan; (3) mengumpulkan data; (4) mengasosiasi; dan (6) mengomunikasikan. Pengukuran keterlaksaan keterampilan bekerja ilmiah siswa dilakukan dengan menggunakan lembar observasi dengan penilaian kinerja siswa oleh observer yang berjumlah 2 orang yang tugasnya mengamati proses kegiatan pembelajaran yang dilakukan baik di kelas maupun di laboratorium.

\section{HASIL DAN PEMBAHASAN}

Berikut ini akan dijelaskan hasil penelitian tentang "Implementasi Model Pembelajaran Discovery untuk Mengembangkan Keterampilan Dasar Bekerja Ilmiah (KDBI) mahasiswa pada Mata Kuliah Konsep Dasar IPA"; Dimulai dari penggunaan model pembelajaran discovery berbasis 


\section{Koordinat Jurnal Pembelajaran Matematika dan Sains}

Vol. 1, No. 1, Juli 2020, Hal. 27-31

praktikum penemuan yang dilakukan pada kelas eksperimen, yang kemudian akan dibandingkan dengan kelas kontrol yang menggunakan model pembelajaran konvensional berbasis praktikum penemuan yang diawali dengan kegiatan membaca. Serta yang ketiga mengenai perkembangan KDBI mahasiswa yang diamati selama proses pembelajaran menggunakan lembar observasi (daftar cek) yang sama antara kelas eksperimen dan kelas kontrol.
Penilaian keterampilan dasar bekerja ilmiah ini dilakukan dengan mengisi lembar observasi kegiatan siswa. Terdapat dua aspek penilaian KDBI yaitu kemunculan aktifitas siswa dan ketepatan aktifitas siswa. Berikut disajikan rangkuman rekapitulasi nilai rata-rata aktifitas belajar siswa pada aspek kemunculan untuk masing-masing indikator dalam KDBI di kelas eksperimen.

Tabel 1: Rekapitulasi Nilai Rata-rata Aktifitas Belajar Mahasiswa dalam KDBI Eksperimen

\begin{tabular}{|c|c|c|c|c|c|c|}
\hline \multirow{2}{*}{$\begin{array}{c}\text { Aktifitas Belajar } \\
\text { Mahasiswa } \\
\text { (Indikator KDBI) }\end{array}$} & \multicolumn{4}{|c|}{$\begin{array}{c}\text { Nilai Aktifitas Belajar pada masing- } \\
\text { masing Sub Materi }\end{array}$} & \multirow{2}{*}{$\begin{array}{l}\text { Nilai } \\
\text { rata- } \\
\text { rata }\end{array}$} & \multirow[b]{2}{*}{ Kriteria } \\
\hline & $\begin{array}{c}\text { Penguku } \\
\text { ran }\end{array}$ & $\begin{array}{l}\text { Gerak } \\
\text { Lurus }\end{array}$ & $\begin{array}{c}\text { Suhu } \\
\text { dan } \\
\text { Kalor }\end{array}$ & $\begin{array}{c}\text { Sumber } \\
\text { Daya } \\
\text { Alam }\end{array}$ & & \\
\hline $\begin{array}{c}\text { Mengamati } \\
\text { Mengajukan } \\
\text { Pertanyaan }\end{array}$ & \multirow[b]{2}{*}{69.8} & \multirow[b]{2}{*}{75.4} & \multirow[b]{2}{*}{82} & \multirow[b]{2}{*}{82.2} & \multirow[b]{2}{*}{77.35} & \multirow[b]{2}{*}{ Baik } \\
\hline $\begin{array}{c}\begin{array}{c}\text { Mengumpulkan } \\
\text { informasi }\end{array} \\
\text { Mengasosiasi } \\
\text { Mengomunikasikan }\end{array}$ & & & & & & \\
\hline
\end{tabular}

Berikut disajikan rangkuman rekapitulasi nilai rata-rata aktifitas belajar siswa pada aspek kemunculan untuk masing-masing indikator dalam KDBI di kelas Kontrol.

Tabel 2: Rekapitulasi Nilai Rata-rata Aktifitas Belajar Mahasiswa pada Aspek Kemunculan dalam KDBI Kelas Kontrol

\begin{tabular}{|c|c|c|c|c|c|c|}
\hline \multirow[b]{2}{*}{ Aktifitas Belajar Siswa } & \multicolumn{4}{|c|}{$\begin{array}{c}\text { Nilai Aktifitas Belajar pada masing- } \\
\text { masing Sub Materi }\end{array}$} & \multirow[b]{2}{*}{$\begin{array}{l}\text { Nilai rata- } \\
\text { rata }\end{array}$} & \multirow[b]{2}{*}{ Kriteria } \\
\hline & $\begin{array}{c}\text { Penguku } \\
\text { ran }\end{array}$ & $\begin{array}{l}\text { Gerak } \\
\text { Lurus }\end{array}$ & $\begin{array}{l}\text { Suhu } \\
\text { dan } \\
\text { Kalor } \\
\end{array}$ & $\begin{array}{c}\text { Sumber } \\
\text { Daya } \\
\text { Alam }\end{array}$ & & \\
\hline Mengamati & \multirow{5}{*}{79.77} & \multirow{5}{*}{74.32} & \multirow{5}{*}{69.09} & \multirow{5}{*}{63.86} & \multirow{5}{*}{71.82} & \multirow{5}{*}{ Cukup } \\
\hline Mengajukan Pertanyaan & & & & & & \\
\hline $\begin{array}{l}\text { Mengumpulkan } \\
\text { informasi }\end{array}$ & & & & & & \\
\hline Mengasosiasi & & & & & & \\
\hline Mengomunikasikan & & & & & & \\
\hline
\end{tabular}

Uji hipotesis dilakukan berdasarkan uji beda perkembangan ratarata nilai aktifitas keterampilan dasar bekerja ilmiah siswa yang diperoleh dari hasil analisis data untuk kelas eksperimen dan untuk kelas kontrol. Uji hipotesis 


\section{Koordinat Jurnal Pembelajaran Matematika dan Sains}

Vol. 1, No. 1, Juli 2020, Hal. 27-31

sebelumnya didahului dengan uji prasyarat yaitu uji normalitas.

Untuk pengujian hipotesis, uji beda rata-rata perkembangan keterampilan dasar bekerja ilmiah siswa pada kelas eksperimen dan kelas kontrol yang disajikan terlihat bahwa terdapat perbedaan perkembangan KDBI yang signifikan antara kelas eksperimen dan kelas kontrol.

\section{KESIMPULAN}

Berdasarkan rumusan masalah yang telah dikemukakan sebelumnya maka diperoleh kesimpulan bahwa terdapat perbedaan perkembangan KDBI yang signifikan antara kelas yang mengimplementasikan model pembelajaran discovery (kelas eksperimen) dengan kelas yang menerapkan model pembelajaran konvensional (kelas kontrol).

\section{DAFTAR PUSTAKA}

Abidin, Y. Desain Sistem Pembelajaran dalam Konteks Kurikulum 2013. PT Refika Aditama. Bandung.

Abimanyu, S. \& Pah, D.N. 1985. Keterampilan Bertanya Dasar dan Lanjut Panduan Pengajaran Mikro 1. Departemen Pendidikan dan Kebudayaan Direktorat Jendral Pendidikan Tinggi Proyek Pengembangan Lembaga Pendidikan Tenaga Kependidikan. Jakarta.

Daryanto. Pembelajaran Tematik, Terpadu, Terintegrasi (Kurikulum 2013). Penerbit Gava Media. Yogyakarta.

Eggen, P., Kauchak, D. Strategi dan Model Pembelajaran: Mengajarkan Konten dan Keterampilan Berpikir Edisi Keenam. PT Indeks. Jakarta. Giancoli, D., C. Fisika Edisi Kelima Jilid 2. Erlangga. Jakarta.
Hamdu, G. Pembelajaran Hidrolisis Garam dengan Model Inkuiri untuk Mengembangkan Kemampuan Dasar bekerja Ilmiah Siswa Kelas XI. Tesis Universitas Pendidikan Indonesia. Tidak Dipublikasikan.

Honomicl, R. \& Chen, Z. Article : The role of guidance in children's discovery learning. John Wiley \& Sons, Ltd. wires.wiley.com/cogsci. Volume 3, November/December 2012.

Hosnan, M. Pendekatan Saintifik dan Kontekstual dalam Pembelajaran Abad 21 Kunci Sukses Implementasi Kurikulum 2013. Penerbit Ghalia Indonesia. Bogor.

Marlina, R. Pemanfaatan Lingkungan Lokal dalam Kegiatan Laboratorium Berbasis Inkuiri terhadap Kerja Ilmiah Mahasiswa Calon Guru Biologi. Tesis. Universitas Pendidikan Indonesia. Tidak Dipublikasikan.

NSTA Board of Directors. NSTA Position Statement Scientific Inquiry.

http://www.nsta.org/about/position s/inquiry.aspx. Diakses rabu, 1211-2014; 10.47 PM.

Purwanto, C. E., Nugroho, S. E., \& Wiyanto. Penerapan Model Pembelajaran Guided Discovery pada Materi Pemantulan Cahaya untuk meningkatkan Berpikir Kritis. Unnes Physics Education Journal. ISSN NO 2257-6935. Dipublikasikan Mei 2012.

Rustaman, N. \& Rustaman, A. (2003). KEMAMPUAN KERJA ILMIAH DALAM SAINS (Karakteristik Kurikulum Berbasis Kompetensi Mata Pelajaran Biologi). Seminar Pendidikan Biologi. Universitas Pasundan. Bandung.

Setiono, K. Psikologi Perkembangan: Kajian Teori Piaget, Selman, 


\section{Koordinat Jurnal Pembelajaran Matematika dan Sains}

Vol. 1, No. 1, Juli 2020, Hal. 27-31

Kohlberg, dan Aplikasi Riset. Penerbit Widya Padjajaran. Bandung.

Sudjana. Metode Statistika. Penerbit Tarsito. Bandung.

Sudjana. Desain dan Analisis Eksperimen Edisi IV. Penerbit Tarsito. Bandung.

Sufyani, S., N. Pemebelajaran Berbasis Proyek untuk Mengembangkan Kemampuan Dasar Bekerja Ilmiah dan Berpikir Kreatif Siswa SMA pada Konsep Pencemaran. Tesis. Universitas Pendidikan Indonesia. Tidak Dipublikasikan.

Sugiyono. Metode Penelitian Kuantitatif Kualitatif dan R\&D. Penerbit Alfabeta. Bandung.

Sukmadinata, N., S. Metode Penelitian Pendidikan. PT Remaja Rosdakarya. Bandung.

Suparno, P. Metodologi Pembelajaran Fisika Konstruktivistik \& Menyenangkan. Penerbit
Universitas Sanata Dharma. Yogyakarta.

Suparno, P. Metode Penelitian Pendidikan IPA. Penerbit Universitas Sanata Dharma. Yogyakarta.

Surakhmad, W. Pengantar Penenlitian Ilmiah: Dasar, Metode, dan Teknik. PT Tarsito. Bandung.

Tawil, M. \& Liliasari. Keterampilanketerampilan Sains dan Implementasinya dalam Pembelajaran IPA. Badan Penerbit Universitas Negeri Makassar. Makasaar.

Tipler, P. Fisika Untuk Sains dan Teknik Edisi Ketiga Jilid 2. Penerbit Erlangga. Jakarta.

Trianto. Model Pembelajaran Terpadu: Konsep, Strategi, dan Implementasinya dalam Kurikulum Tingkat Satuan Pendidikan (KTSP). PT Bumi Aksara. Jakarta. 